\title{
Effects of dietary zinc deficiency on gonadotrophin secretion and testicular growth in young male sheep
}

\author{
G. B. Martin ${ }^{1,2}$ and C. L. White ${ }^{2}$ \\ ${ }^{1}$ School of Agriculture (Animal Science), The University of Western Australia, Nedlands, WA \\ 6009, Australia; and ${ }^{2}$ CSIRO Division of Animal Production, Private Bag, Wembley, WA 6014, \\ Australia
}

\begin{abstract}
Summary. The hypothesis that the secretion of gonadotrophins would be reduced by zinc deficiency was tested in five groups of four young Merino rams (initial liveweight $22 \mathrm{~kg}$ ). Four groups were fed ad libitum with diets containing 4, 10, 17 or $27 \mu \mathrm{g} \mathrm{Zn} \mathrm{g}^{-1}$. The effects of loss of appetite on the deficient diet was controlled by feeding a fifth group (pair-fed control) at a rate of $27 \mu \mathrm{g} \mathrm{Zn} \mathrm{g}{ }^{-1}$, but the amount of feed offered was restricted to that eaten voluntarily by the deficient $\left(4 \mu \mathrm{gn} \mathrm{g}^{-1}\right)$ group. Blood was sampled every $20 \mathrm{~min}$ for $32 \mathrm{~h}$ on two occasions before the treatments were imposed and 96 days later, at the end of the experiment. The rams were injected with gonadotrophin-releasing hormone ( $\mathrm{GnRH} ; 10 \mathrm{ng} \mathrm{kg}^{-1}$ i.v.) after each serial sampling, and with naloxone ( $1 \mathrm{mg} \mathrm{kg}^{-1}$ i.v.) $24 \mathrm{~h}$ after the end of the final $\mathrm{GnRH}$ test.

In the group that were fed the diet with the lowest zinc content, the concentration of zinc in blood plasma was reduced to $18 \%$ of that in the pair-fed controls $(P<0.05)$ and was within the deficient range. The appetite of the deficient rams was half that of the controls fed $27 \mu \mathrm{g} \mathrm{Zn} \mathrm{g}^{-1}$ ad libitum and there was no increase in liveweight or testicular diameter during pubertal development. Similar, but smaller, effects were observed in the pair-fed controls. There were no significant differences between pair-fed and deficient groups in the frequency of the luteinizing hormone $(\mathrm{LH})$ pulses or in the concentration of follicle-stimulating hormone (FSH), but the secretion of gonadotrophins was markedly lower in both groups than in the control rams fed ad libitum. The response to GnRH was not affected by treatment, but the increase in LH pulse frequency evoked by naloxone was lower in the deficient animals than in other groups. The animals fed zinc at intermediate rates $\left(10-17 \mu \mathrm{g} \mathrm{g}^{-1}\right)$ showed similar responses to the controls fed ad libitum.

It is concluded that the specific effects of zinc deficiency on testicular function were small. Most of the reduction in testicular growth in rams fed a deficient diet was not specifically related to the trace element, but was due to the fall in energy and protein intake caused by the loss of appetite. This leads to a reduction in the frequency of GnRH pulses secreted by the hypothalamus, and to low rates of gonadotrophin secretion by the pituitary gland.
\end{abstract}

Keywords: zinc; testis; gonadotrophin; nutrition; sheep

\section{Introduction}

Zinc is an essential trace element and many physiological processes are impaired if it is not supplied in sufficient quantities in the diet. In 1969, Underwood \& Somers suggested that there may be two degrees of zinc deficiency in growing rams: 'severe' deficiency ( $<5 \mu \mathrm{g} \mathrm{Zn} \mathrm{g}^{-1}$ diet) which induces skin lesions (parakeratosis), low growth rates and poor testicular development; and 'mild' 
deficiency (5-17 $\mu \mathrm{g} \mathrm{Zn}^{-1}$ ) where there are no clinical symptoms and body growth is normal, but testicular development and sperm production are markedly reduced.

This contrast between the responses of the reproductive and other tissues suggests that 'mild' deficiency specifically affects the hormonal systems controlling testicular growth. A similar situation has been suggested for the male rat and human, in which the effects of zinc deficiency appear to be expressed in the testis, specifically within the pathways controlling steroidogenesis, so that the secretion of androgens is reduced (McClain et al., 1984; Prasad, 1985; Hafiez et al., 1989). In several studies, there was an increase in the secretion of gonadotrophins, presumably as a consequence of the loss of negative feedback to the hypothalamo-hypophyseal system (Lei et al., 1976; Root et al., 1979; Prasad, 1985). In the study by Hafiez et al. (1989), however, the serum concentrations of gonadotrophins were not affected.

We therefore decided to investigate these effects further in the ram, a species in which we can analyse the hypothalamic and pituitary responses in detail by studying the pulsatile patterns of secretion of luteinizing hormone $(\mathrm{LH})$. We fed pubertal rams with diets containing a range of concentrations of zinc, from deficient through to adequate. We measured testicular growth, $\mathrm{LH}$ pulse frequency, follicle-stimulating hormone (FSH) concentrations, hypothalamic responsiveness to an opioid antagonist, and pituitary responsiveness to gonadotrophin-releasing hormone (GnRH). A pair-fed control was included in the design so that we could account for the effects of loss of appetite and assess whether the effects of deficiency reflected specific responses of a mechanism involving zinc, or nonspecific responses to deficits of energy and protein. Preliminary reports of this work have been presented elsewhere (Martin \& White, 1989a, b).

\section{Materials and Methods}

\section{Animals and treatments}

In November (late spring), five groups of four rams (age 16 weeks, mean liveweight $22 \mathrm{~kg}$ ) were penned individually in an animal house that was well lit by natural light (i.e. approximately normal photoperiod for latitude $32^{\circ} \mathrm{S}$ ). During an acclimatization period of 2 weeks, they were given ad libitum access to deionized water and a semipurified chaff diet that formed the basis of the dietary treatments, except that it contained $27 \mu \mathrm{g} \mathrm{Zn} \mathrm{g}^{-1}$. After being randomly allocated to treatments, the animals in four of these groups were fed ad libitum with diets containing either 27 ('ad libitum control'), 4 ('deficient'), 10 or $17 \mu \mathrm{g} \mathrm{Zn} \mathrm{g}{ }^{-1}$. The rams in the fifth group, the 'pair-fed control', were fed the diet containing $27 \mu \mathrm{Zn} \mathrm{g}^{-1}$, but each animal was paired with an animal from the deficient group and fed only the amount eaten voluntarily by its pair during the previous day. Once each week, just before feeding, the animals were weighed and the diameters of both testes were measured with calipers.

\section{Diets}

The concentration of zinc in the basal diet (Table 1) was $3.9 \mu \mathrm{g} \mathrm{Zn} \mathrm{g}^{-1}$ and $\mathrm{ZnSO}_{4} \cdot 7 \mathrm{H}_{2} \mathrm{O}$ was added for the other treatments. The sheep were injected once a week (i.m.) with $0.5 \mathrm{ml}$ of a vitamin B complex (Richtasol Duo-B complex: Ausrichter Pty Ltd, Artarmon, NSW, Australia) containing $0.1 \mathrm{mg}$ added biotin, $0.6 \mathrm{mg}$ thiamin hydrochloride, $0.6 \mathrm{mg}$ pyridoxine hydrochloride, $0.23 \mathrm{mg}$ riboflavin phosphate, $1.9 \mathrm{mg}$ nicotinic acid, $0.6 \mathrm{mg}$ sodium pantothenate and $6.3 \mu \mathrm{g}$ cyanocobalamin. Once a month the animals were also given injections of Duphafral Forte, a mixture containing 250000 units of vitamins $A$ (as retinol), 25000 units of vitamin $D_{3}$ and 25 units of DL $\alpha$-tocopherol in $0.5 \mathrm{ml}$ vehicle. The vitamin supplements were necessary because of the pure nature of the synthetic diet and the possibility that zinc deficiency would reduce the production of water-soluble vitamins by the rumen microorganisms.

\section{Collection of blood samples}

For the detailed analysis of LH pulses and FSH concentrations, blood was sampled every $20 \mathrm{~min}$ for $32 \mathrm{~h}$ from jugular catheters inserted the day before sampling. This was done on two occasions, just before the imposition of treatments and 92 days later at the end of the experiment. At the end of each intensive sampling period, the pituitary responsiveness of the animals was tested by injecting them intravenously with GnRH ('HRF': Ayerst Laboratories Pty Ltd, Parramatta, NSW, Australia; $10 \mathrm{ng} \mathrm{kg}^{-1}$ in saline) and taking further samples at 0,10 and $20 \mathrm{~min}$, and then every $20 \mathrm{~min}$ for $4 \mathrm{~h}$ after the injection. The animals were injected intravenously with naloxone (Sigma Chemical Company, St Louis, Missouri, USA; $1 \mathrm{mg} \mathrm{kg}^{-1}$ in saline) about $24 \mathrm{~h}$ after the final serial sampling, and blood was sampled every $10 \mathrm{~min}$ for $4 \mathrm{~h}$. All sheep were injected with $5 \mathrm{ml}$ procaine penicillin after the first serial sampling. 
were $0.0292\left(b_{1}\right.$, the $y$ intercept), $0.0697\left(b_{2}\right.$, the $x$ coefficient $)$ and $0.00089\left(b_{3}\right.$, the $x^{2}$ coefficient). The inter-pulse interval, nadir (minimum concentration observed up to $35 \mathrm{~min}$ before the peak of a pulse) and pulse amplitude (the difference between pulse peak and preceding nadir) were calculated for each pulse and means for each profile were used in the analysis of treatment effects.

\section{Statistical analysis}

Except where otherwise stated, the data were tested for time and treatment effects by repeated measures analysis of variance and, when significant effects were detected $(P \leqslant 0.05)$, individual means were compared using the least significant difference. Where the variance was proportional to the mean, the data were transformed logarithmically before statistical analysis. The deficient and pair-fed controls were paired for quantity of feed consumed, so paired $t$-tests were also used to compare these groups.

\section{Results}

\section{Liveweight, feed intake and zinc in plasma}

Voluntary feed intake was severely reduced in the animals fed the deficient diet (Table 2), relative to all groups except pair-fed controls. The difference between the deficient and pair-fed groups represented only $1 \cdot 2 \%$ of total dry matter intake and was caused by small day-to-day differences in the amounts offered, particularly during the early stages of the experiment when the deficiency had little or no effect on appetite. There were no significant differences between the intakes of the groups fed 10,17 or $27 \mu \mathrm{g} \mathrm{Zn}^{-1}$ ad libitum.

The liveweights of the animals at the end of the experiment reflected the feed intakes, with very little growth in the deficient or pair-fed rams and a similar amount of growth in all other groups. The concentration of zinc in blood plasma was related to dietary content, the deficient group having low $\mathrm{Zn}$ values significantly different from both pair-fed and ad libitum controls. The values for the group fed $10 \mu \mathrm{g} \mathrm{Zn} \mathrm{g}^{-1}$ were intermediate between those observed in the deficient and control groups. The animals fed $4 \mu \mathrm{g} \mathrm{Zn} \mathrm{g}^{-1}$ developed the pathological signs normally associated with zinc deficiency, including skin lesions around the mouth, feet and eyes, loss of the wool from scrotal skin, the production of copious quantities of frothy saliva, and the secretion of watery mucus from the eyes (Underwood, 1981).

Table 2. Effects of dietary zinc on liveweight and concentrations of zinc in plasma (after treatment for 96 days) and voluntary food intake (dry weight averaged over days $0-90$ of the experiment) in Merino rams

\begin{tabular}{lcccc}
\hline Treatment & $\begin{array}{c}\text { Dietary zinc } \\
\left(\mu \mathrm{g} \mathrm{g}^{-1}\right)\end{array}$ & $\begin{array}{c}\text { Feed intake } \\
\left(\mathrm{g} \mathrm{day}^{-1}\right)\end{array}$ & $\begin{array}{c}\text { Liveweight } \\
(\mathrm{kg})\end{array}$ & $\begin{array}{c}\text { Plasma zinc } \\
\left(\mathrm{mg}^{-1}\right)\end{array}$ \\
\hline Deficient & $3 \cdot 9 \pm 0 \cdot 17$ & $693 \pm 72^{\mathrm{a}}$ & $25 \pm 1^{\mathrm{a}}$ & $0 \cdot 08 \pm 0.01^{\mathrm{a}}$ \\
$10 \mu \mathrm{g} \mathrm{Zn} \mathrm{g} \mathrm{g}^{-1}$ & $10 \cdot 3 \pm 1 \cdot 5$ & $1316 \pm 59^{\mathrm{b}}$ & $43 \pm 2^{\mathrm{b}}$ & $0 \cdot 43 \pm 0 \cdot 11^{\mathrm{b}}$ \\
$17 \mu \mathrm{g} \mathrm{Zn} \mathrm{g}$ & $16 \cdot 7 \pm 0 \cdot 5$ & $141 \pm \pm 51^{\mathrm{b}}$ & $43 \pm 2^{\mathrm{b}}$ & $0 \cdot 64 \pm 0.05^{\mathrm{c}}$ \\
Control (pair-fed) & $27 \cdot 2 \pm 1 \cdot 86$ & $703 \pm 67^{\mathrm{a}}$ & $29 \pm 3^{\mathrm{a} *}$ & $0 \cdot 66 \pm 0.08^{\mathrm{c}}$ \\
Control (ad libitum) & $27 \cdot 2 \pm 1 \cdot 86$ & $1532 \pm 97^{\mathrm{b}}$ & $42 \pm 1^{\mathrm{b}}$ & $0 \cdot 83 \pm 0.07^{\mathrm{c}}$ \\
\hline
\end{tabular}

Values are means $\pm \mathrm{SEM} ; n=4$ per group.

${ }^{a, b, c}$ Different superscripts within columns indicate significant differences (analysis of variance, $P<0.05$ ).

*Deficient and pair-fed differ significantly $(P<0.05$, paired t test $)$.

\section{Testicular growth}

As the experiment progressed, the testes of the rams fed diets containing zinc at 17 and $27 \mu \mathrm{gn}$ $\mathrm{g}^{-1}$ (ad libitum) increased in diameter (Fig. 1). A similar pattern was observed in the animals fed 
$10 \mu \mathrm{gn} \mathrm{g}^{-1}$ but, towards the end of the experiment, growth rate was reduced more than in the animals fed 17 or $27 \mu \mathrm{g} \mathrm{Zn} \mathrm{g}^{-1}$ ad libitum and they showed less total growth (Fig. 1b). In contrast, testicular growth was severely restricted in the pair-fed controls and completely blocked in the deficient animals.
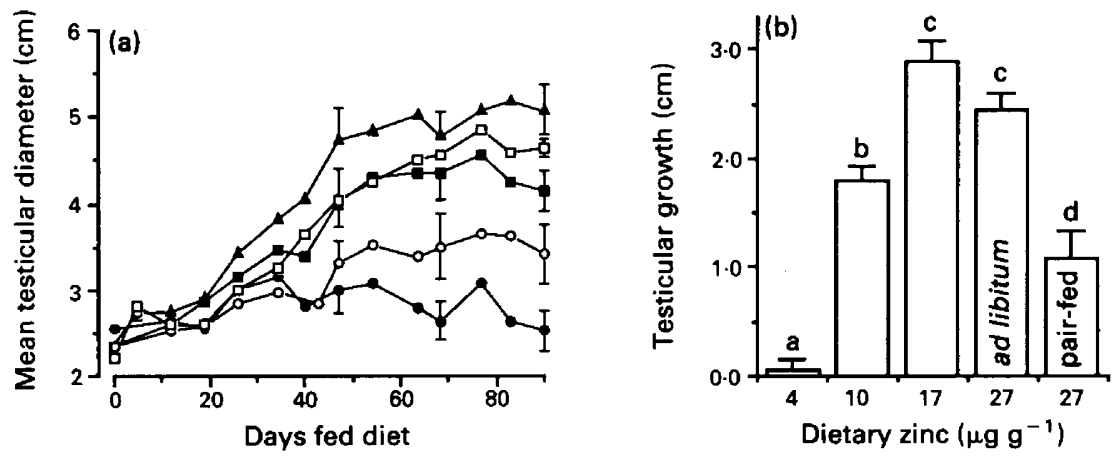

Fig. 1. Effects of dietary zinc on the (a) diameter (mean for each animal) and (b) growth (difference between original and final diameters) of testes in rams fed diets containing $4(\boldsymbol{O}), 10(\boldsymbol{\square})$, $17(\Delta)$ or $27 \mu \mathrm{g} \mathrm{Zn} \mathrm{g}^{-1}$ ad libitum $(\square)$ or pair-fed $(O)$. All values are means $\pm \operatorname{SEM}(n=4)$. Columns with different letters are significantly different $(P<0.05)$.

\section{Plasma LH}

Plasma LH pulses were easily identified in all profiles at both stages of the experiment (Fig. 2). The phenomenon of 'multiple pulses', in which the $24 \mathrm{~h}$ period contained a large number of identifiable pulses that were grouped into pairs or triplets, was evident in all groups during the pretreatment sampling, but they were rare during the sampling at the end of the experiment.

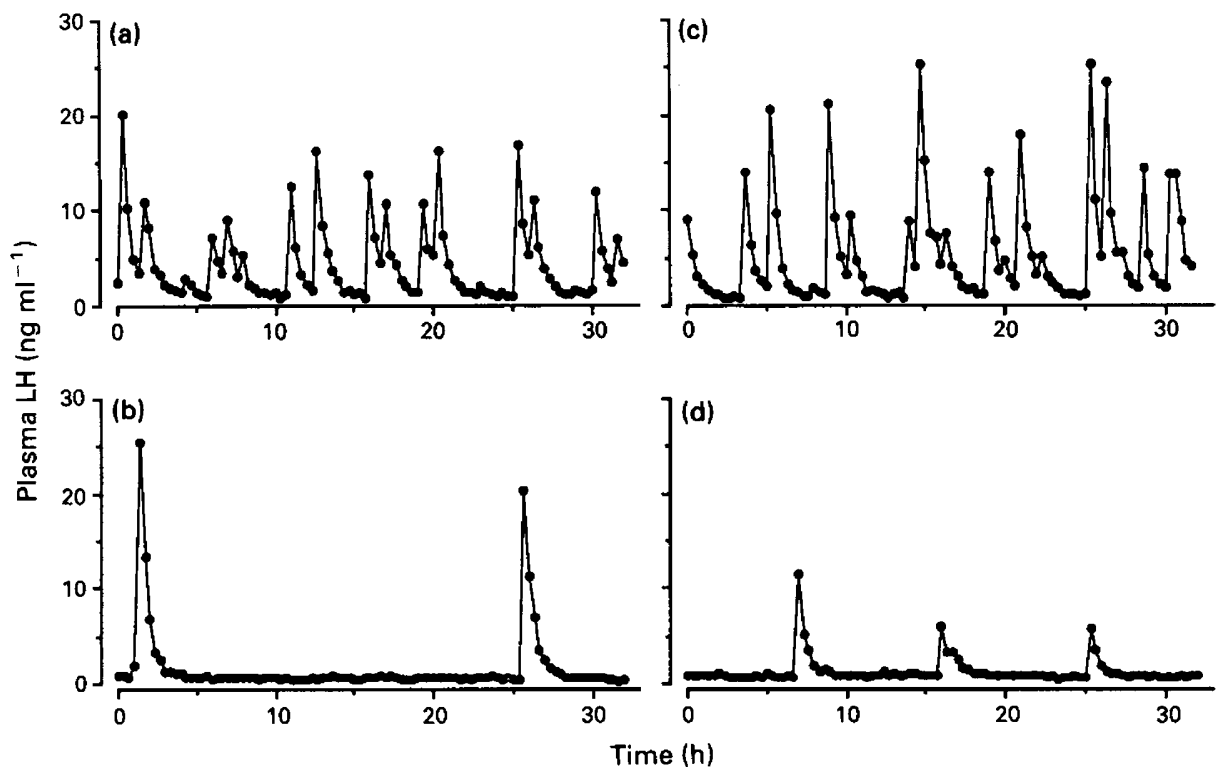

Fig. 2. Patterns of secretion of luteinizing hormone (LH) in two rams before (a,c) and after $(b, d)$ treatment, demonstrating the multiple pulses observed when the pulse frequency was high (a, b: pair-fed control; c, d: deficient). 

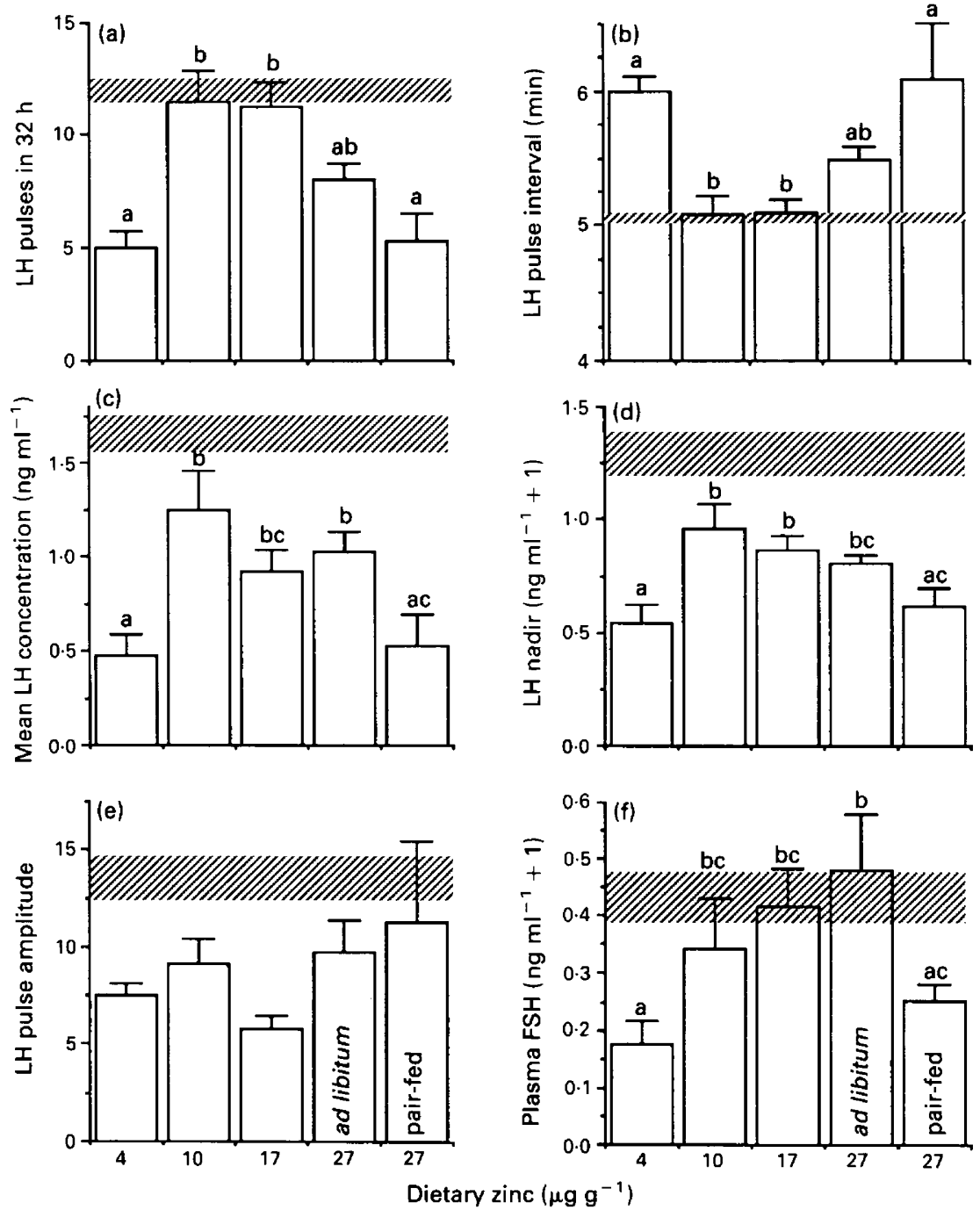

Fig. 3. Secretion of gonadotrophins in young male sheep fed diets containing (a) 4, (b) 10 , (c) 17 or (d) $27 \mu \mathrm{g} \mathrm{Zn} \mathrm{g}{ }^{-1}$ fed ad libitum or (e) pair-fed, as assessed in samples taken every $20 \mathrm{~min}$ (luteinizing hormone, LH) or (f) every $2 \mathrm{~h}$ (follicle-stimulating hormone, FSH) for $24 \mathrm{~h}$. The shaded horizontal bar represents the mean $( \pm \operatorname{SEM}, n=20)$ of the values observed for all the animals combined before the dietary treatments were imposed, and the histograms represent the values (mean \pm SEM, $n=4$ per group) observed after 92 days of treatment. Columns with different letters are significantly different: $P<0.05$.

Pulse frequency. There was a significant interaction $(P<0 \cdot 001$, repeated measures analysis of variance) between treatment and time because the frequency decreased between the sampling periods. The size of the decrease varied markedly among treatments (Fig. 3a). The frequency fell in the deficient rams and the pair-fed and ad libitum controls, but remained similar to pretreatment values in the animals fed either 10 or $17 \mu \mathrm{g} \mathrm{Zn} \mathrm{g}^{-1}$. The largest falls were observed in the deficient and pair-fed animals, and these groups did not differ significantly. The differences in frequency between these groups and the ad libitum controls were not significant. Analysis of pulse intervals (Fig. $3 b$ ) revealed the same effects. 

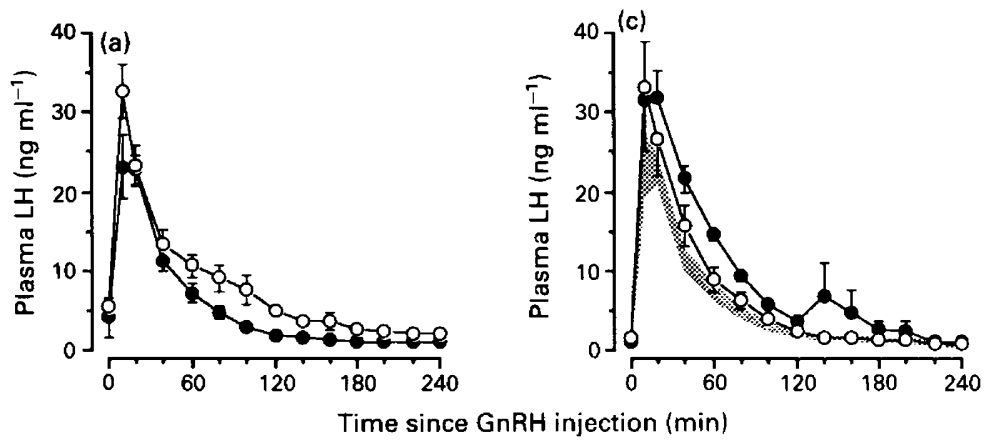

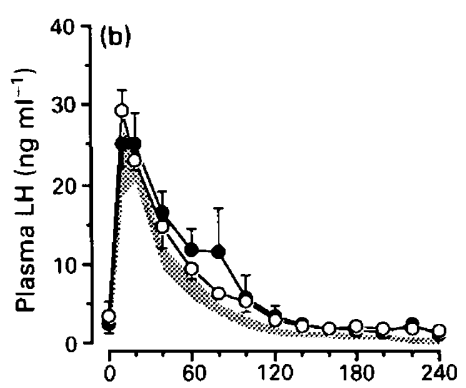

Time since $\mathrm{GnRH}$ injection ( $\mathrm{min}$ )

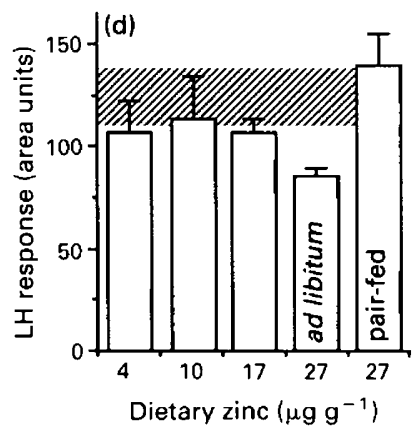

Fig. 4. Effects of dietary zinc on the pituitary response of young male sheep to $10 \mathrm{ng}$ gonadotrophin-releasing hormone $(\mathrm{GnRH}) \mathrm{kg}^{-1}$ (i.v.). (a) fed at $27 \mu \mathrm{g} \mathrm{Zn} \mathrm{g}{ }^{-1}$ (ad libitum) before treatment $(\bigcirc)$ and after 92 days on the diet (๑); (b) fed at $10(\odot)$ or 17 (○) $\mu \mathrm{g} \mathrm{Zn} \mathrm{g} \mathrm{Zn}^{-1}$ compared with the control fed $27 \mu \mathrm{g} \mathrm{Zn} \mathrm{g}^{-1}$ ad libitum (shaded area); (c) fed at 27 (pair-fed control, - ) or 4 (deficient, $\bigcirc) \mu \mathrm{gn} \mathrm{g}^{-1}$ compared with the control fed $27 \mu \mathrm{g} \mathrm{Zn} \mathrm{g}^{-1}$ ad libitum (shaded area); (d) response to $\mathrm{GnRH}$ after 92 days of treatment, as measured by area under the luteinizing hormone (LH) curve, in rams fed diets containing 4, 10, 17 or $27 \mu \mathrm{g}$ $\mathrm{Zn}^{-1}$ (ad libitum or pair-fed). The shaded area represents the mean $( \pm \operatorname{SEM}, n=20)$ of the areas observed before the treatments were imposed; all other values, mean $\pm \operatorname{SEM}(n=4)$.

Concentrations. Mean and interpulse nadir concentrations of $\mathrm{LH}$ also fell as the experiment progressed $(P<0.001)$, but the interactions were not significant, suggesting that the responses to the dietary treatments were not affected by time (Fig. 3c, d). The changes over time were large relative to the differences among groups, so the log-transformed data from the end of the experiment were subjected to one-way analysis of variance. There was an effect of diet $(P=0.008)$ on mean concentration: the values for the pair-fed control and deficient animals were not significantly different, but were significantly lower than those in the other groups (except for the comparison of $17 \mu \mathrm{g} \mathrm{g}^{-1}$ and pair-fed controls). The values for animals fed 10,17 or $27 \mu \mathrm{g} \mathrm{g}^{-1}$ ad libitum did not differ significantly. The effects of diet on inter-pulse nadir $(P=0.017)$ were similar: the values for the pair-fed control and deficient animals were not significantly different, but were significantly lower than those in the other groups (except for the comparison of the two groups fed $27 \mu \mathrm{g} \mathrm{g}^{-1}$ ). The values for animals fed zinc at concentrations of 10,17 or $27 \mu \mathrm{g} \mathrm{g}^{-1}$ ad libitum did not differ significantly.

Pulse amplitudes. Pulse amplitudes were also significantly affected by time $(P=0.003)$ because the values decreased as the experiment progressed, but there was no effect of diet (Fig. 3e).

\section{Plasma FSH}

In contrast to $\mathrm{LH}$, the concentrations of FSH did not change significantly as the experiment progressed (Fig. 3f). For the final intensive sampling period, there was an effect of diet 

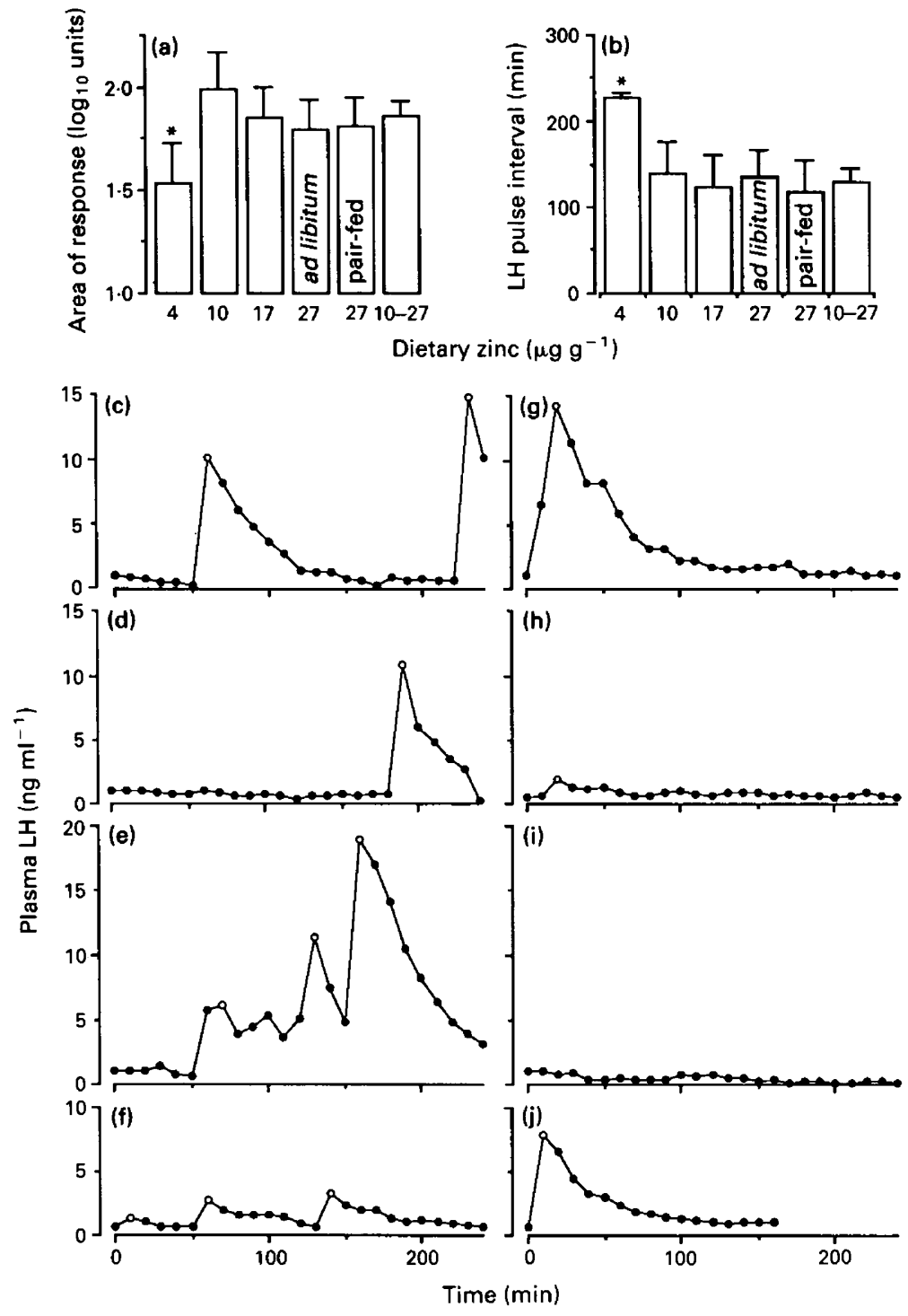

Fig. 5. Effects of dietary zinc on (a) the area under the luteinizing hormone (LH) response curve and (b) the interpulse interval in young male sheep injected with $1 \mathrm{mg}$ naloxone $\mathrm{kg}^{-1}$ (i.v.). ${ }^{*} P<0.05$ compared with combined treatments. All values are means $\pm \operatorname{SEM}(n=4)$. In the LH profiles for four pair-fed control rams (c-f) and four deficient rams $(g-j),(O)$ : peaks of significant pulses.

$(P=0.046)$ and between-group comparisons showed that the concentrations of FSH were significantly lower in the deficient animals than in the animals fed zinc at concentrations of either 17 or $27 \mu \mathrm{g} \mathrm{g}^{-1}$ ad libitum. The values for the pair-fed controls were similar to those of the deficient animals and were also significantly lower than those of the ad libitum group, but did not differ from any other treatment. If the pair-fed controls were omitted, there was a significant relationship between dietary zinc concentration and plasma FSH concentration $\left(R^{2}=0 \cdot 28\right.$; $P=0.034)$. 


\section{Response to GnRH}

The responses to $\mathrm{GnRH}$ were consistent between sampling times and between groups at the final sampling (Fig. 4). The amplitudes of the responses ranged from $20-40 \mathrm{ng} \mathrm{ml}^{-1}$, about twice the values observed for pulses secreted endogenously (Fig. 3). The tendency for the profiles to diverge 1-2 h after $\mathrm{GnRH}$ injection was due to interference by endogenous pulses in some animals in the group, particularly in the pretreatment period when all animals had a high frequency of pulses. There was no significant effect of time or diet on either the amplitude of the response or the area under the response curve (Fig. 4).

\section{Response to naloxone}

The injection of naloxone evoked pulses of LH in most animals. Analysis of the resulting data revealed no differences between any of the groups fed $10-27 \mu \mathrm{g} \mathrm{Zn}^{-1}$. The pulse profiles from the deficient and pair-fed rams appeared to differ qualitatively (Fig. 5) and significant effects became apparent when the data for all groups fed $10-27 \mu \mathrm{gn} \mathrm{g}^{-1}$ were pooled and compared with the deficient group. The response to naloxone was significantly smaller in terms of the frequency of pulses evoked, and the area under the response curve (Fig. 5a, b). Among the other variables (amplitude, mean concentration, nadir), there were no significant differences (data not shown).

\section{Discussion}

Zinc deficiency completely blocked testicular growth in young rams, but comparison of the responses in the deficient animals with those in the pair-fed and ad libitum control groups showed that most of this response was due to the loss of appetite. The consequent lack of energy and protein needed for growth and pubertal development led to a profound reduction in the secretion of $\mathrm{LH}$ pulses and FSH, and this was undoubtedly a major factor limiting testicular growth. The effects on pulse frequency suggest that the responses to energy and protein are exerted at the hypothalamic level and expressed through the neural network controlling the frequency of GnRH pulses (Thiéry \& Martin, 1991).

In the present study, there was a general reduction in the concentrations of FSH and in the frequency and amplitude of the LH pulses as the experiment progressed. This was probably due to increases in the rates of secretion of testosterone and inhibin as the rams matured and their testes developed. Interestingly, LH pulse frequency and FSH concentrations were positively correlated in most circumstances, the exception being in the ad libitum controls where LH pulse frequency was low at the end of the experiment while FSH concentrations remained high. In several other instances also, the animals on this diet differed from those fed $17 \mu \mathrm{g} \mathrm{Zn} \mathrm{g}^{-1}$. The patterns of testicular growth were similar, suggesting that negative feedback was more effective in the ad libitum controls than in the $10-17 \mu \mathrm{g} \mathrm{Zn}^{-1}$ groups, perhaps owing to subtle effects of mild deficiency at the lower concentrations of zinc.

In addition, the plasma concentrations of FSH appeared to be dose dependent over the range 4-17 $\mu \mathrm{g} \mathrm{Zn}^{-1}$ and testicular development tended to be lower at 10 than at $17 \mu \mathrm{g} \mathrm{Zn} \mathrm{g}^{-1}$. Thus, the data from the groups fed intermediate concentrations of zinc support the suggestion by Underwood \& Somers (1969) that testicular tissue differs from other zinc-dependent body components in terms of requirements for zinc. However, the difference we observed was small and the effects differ from those reported by Underwood \& Somers (1969). They observed significantly lower testicular growth at 17 than at $32 \mu \mathrm{g} \mathrm{Zn} \mathrm{g}^{-1}$. All our data show that $17 \mu \mathrm{g} \mathrm{Zn}^{-1}$ is adequate. We suggest that, if there is a critical level of zinc, it will be closer to $10 \mu \mathrm{g} \mathrm{Zn} \mathrm{g}^{-1}$. Similar conclusions were drawn by Hatch et al. (1987), who found no differences in testicular growth in rams fed dietary zinc over the range $22-47 \mu \mathrm{g} \mathrm{Zn} \mathrm{g}^{-1}$. There is still some doubt and a more detailed 
study with a larger number of animals might be needed before firm conclusions can be drawn. It is apparent from field studies with large flocks (Masters \& Somers, 1980) that any effects will be subtle, perhaps too subtle for current techniques to reveal in detailed laboratory analysis of small groups of animals.

The hypothalamic response to naloxone was not affected by restricting the amount of feed allocated to the animals, suggesting that the opioid system is not directly involved in the regulation of responses to food supply, in contrast to its apparent role in responses to photoperiod (Lincoln et al., 1987). On the other hand, the response to naloxone was reduced by zinc deficiency, suggesting that the opioid tone was lower in these animals than in the controls. Since the activity of the opioid system that controls GnRH secretion depends on the amount of feedback exerted by testosterone (Lincoln et al., 1987), it seems likely that the deficient rams produce less testosterone than the pairfed controls (Martin \& White, 1989a). However, the responses to naloxone should be regarded with some caution as they varied greatly among animals and this aspect of the work needs to be repeated with more animals before firm conclusions can be drawn.

In rams, the frequency of LH pulses secreted by the pituitary gland is controlled on a one-toone basis by the frequency of GnRH pulses secreted by the hypothalamus (Caraty et al., 1987); a low LH pulse frequency therefore reflects the response of the reproductive centres of the hypothalamus to a lack of metabolic substrates. Similar responses have been observed in ewe lambs when puberty is delayed by underfeeding (Foster \& Olster, 1985) and in adult rams subjected to changes in food availability (Martin et al., 1990). The frequency of GnRH pulses is the primary signal controlling testicular development (Lincoln, 1979a). Apart from determining LH pulse frequency, the GnRH signal also controls the concentration of FSH (Lincoln, 1979b), though the secretion of this hormone is also strongly affected by testosterone and inhibin from the testes feeding back directly to the pituitary gland (Tjondronegoro et al., 1991).

The phenomenon of multiple or grouped pulses of $\mathrm{LH}$ during periods of rapid testicular growth has now been observed in both pubertal (present study) and adult rams (Martin et al., 1987a).

Each LH pulse within a group evokes a pulse of testosterone so the testis is stimulated more than once by each group (Martin et al., 1987a). The number of multiple pulses strongly affects the values for inter-pulse nadir, so the fall in their frequency between sampling periods explains much of the time-dependent changes that were observed in this study.

The results from most comparable studies with zinc-deficient rats and men differ from the present data in one key area, namely the rates of secretion of gonadotrophins. In deficient rams, the secretion of LH and FSH were both reduced whereas, in the other species, the secretion of gonadotrophins is increased, apparently because poor testicular development leads to low rates of testosterone secretion (Lei et al., 1976; Root et al., 1979; Prasad, 1985). Superficially, this latter observation is more consistent with our understanding of the control of gonadotrophin secretion by the processes of negative feedback, leading us to ask why the ram is different. The LH pulse frequencies of the ad libitum and pair-fed controls provide part of the answer, showing that the restriction of feed intake strongly depressed hypothalamic activity, at least with regard to the frequency of GnRH pulses. In the deficient rams, this effect probably masked any responses to the reductions in negative feedback (indicated by the reduced responses to naloxone in the deficient group), a possibility that needs to be tested in castrated animals.

In conclusion, the poor testicular growth in zinc-deficient rams is mostly a nonspecific response to the loss of appetite associated with the deficiency. The consequent lack of energy and protein reduces the secretion of $\mathrm{LH}$ and FSH, key hormones in the control of testicular function.

This work was supported by grants from the Joint CSIRO-University of Western Australia Research Fund, the Australian Research Council, the Wool Research Trust Fund and the Australian Pastoral Research Trust. We would like to thank the following people for their technical assistance: M. Barnes, M. Blackberry, J. Briegel, P. Cransberg, R. Holme, S. Roe and D. Suckling. 


\section{References}

Caraty, A., Locatelli, A. \& Schanbacher, B.D. (1987) Augmentation par la naloxone de la fréquence et de Pamplitude des pulses de LH-RH dans le sang porte hypothalamo-hypophysaire chez le bélier castré. Comptes Rendus hebdomadaires des Séances, Academie des Sciences, (Paris) 305, 369-374.

Foster, D.L. \& Olster, D.H. (1985) Effect of restricted nutrition on puberty in the lamb: patterns of tonic luteinizing hormone (LH) secretion and competency of the LH surge. Endocrinology 116, 375-381.

Hafiez, A.A., El-Kidassy, Z.H.M., Mansour, M.M.S., Sharada, H.M. \& El-Zayat, E.M.I. (1989) Role of zinc in regulating the testicular function. Part 1. Effect of dietary zinc deficiency on serum levels of gonadotropins, prolactin and testosterone in male albino rats. Die Nahrung 33 10, 935-940.

Hatch, P.A., Spears, J.W., Goode, L. \& Johnson, B.H. (1987) Influence of dietary zinc on growth and testicular development in ram lambs fed a high fiber diet. Nutrition Reports International 35, 1175-1183.

Lei, K.Y., Abbasi, A.A. \& Prasad, A.S. (1976) Function of the pituitary-gonadal axis in zinc-deficient rats. American Journal of Physiology 230, 1730-1732.

Lincoln, G.A. (1979a) Use of pulsed infusion of luteinizing hormone releasing hormone to mimic seasonally induced endocrine changes in the ram. Journal of Endocrinology 83, 251-260.

Lincoln, G.A. (1979b) Differential control of luteinizing hormone and follicle-stimulating hormone by luteinizing hormone releasing hormone in the ram. Journal of Endocrinology 80, 133-140.

Lincoln, G.A., Ebling, F.J.P. \& Martin, G.B. (1987) Endogenous opioid control of pulsatile LH secretion in rams: modulation by photoperiod and gonadal steroids. Journal of Endocrinology 115, 425-438.

MeClain, C.J., Gavaler, J.S. \& van Thiel, D.H. (1984) Hypogonadism in the zinc-deficient rat: localization of the functional abnormalities. Journal of Laboratory and Clinical Medicine 104, 1007-1015.

McNeilly, J.R., McNeilly, A.S., Walton, J.S. \& Cunningham, F.J. (1976) Development and application of a heterologous radioimmunoassay for ovine follicie-stimulating hormone. Journal of Endocrinology 70, 69-79.

Martin, G.B. \& White, C.L. (1989a) The effect of zinc deficiency on reproduction in the ram. Journal of Trace Elements in Experimental Medicine 2, 170.

Martin, G.B. \& White, C.L. (1989b) Effects of dietary zinc deficiency on testicular growth and gonadotrophin secretion in rams. Proceedings of the Australian Society for Reproductive Biology 21, 11.

Martin, G.B., Oldham, C.M. \& Lindsay, D.R. (1980) Increased plasma LH levels in seasonally anovular
Merino ewes following the introduction of rams. Animal Reproduction Science 3, 125-132.

Martin, G.B., Sutherland, S.R.D. \& Lindsay, D.R. (1987a) Effects of nutritional supplements on testicular size and the secretion of $\mathrm{LH}$ and testosterone in Merino and Booroola rams. Animal Reproduction Science 12, 267-281.

Martin, G.B., Taylor, P.L. \& McNeilly, A.S. (1987b) Effect of small doses of bovine follicular fluid on the tonic secretion of gonadotrophins in the ewe. Journal of Endocrinology 114, 73-79.

Martin, G.B., Ford, J.R. \& Purvis, I.W. (1990) Environmental and genetic factors affecting reproductive activity in the Merino ram. In Reproductive Physiology of Merino Sheep - Concepts and Consequences pp. 111-129. Eds C. M. Oldham, G. B. Martin \& I. W. Purvis. School of Agriculture (Animal Science): The University of Western Australia, Perth.

Masters, D.G. \& Somers, M. (1980) Zinc status of grazing sheep: seasonal changes in zinc concentrations in plasma, wool and pasture. Australian Journal of Experimental Agriculture and Animal Husbandry 20, 20-24.

Merriam, G.R. \& Wachter, K.W. (1982) Algorithms for the study of episodic hormone secretion. American Journal of Physiology 243, E310-E318.

Prasad, A.S. (1985) Clinical, endocrinological and biochemical effects of zinc deficiency. Clinics in Endocrinology and Metabolism 14, 567-589.

Root, A.W., Duckett, G., Sweetland, M. \& Reiter, E.O. (1979) Effects of zinc deficiency upon pituitary function in sexually mature and immature male rats. Journal of Nutrition 109, 958-964.

Thiéry, J-C. \& Martin, G.B. (1991) Neurophysiological control of the secretion of gonadotrophin-releasing hormone and luteinising hormone in the sheep-a review. Reproduction, Fertility and Development 3, 137-173.

Tjondronegoro, S., Martin, G.B., Sutherland, S.R.D., Boukhliq, R. \& Adams, N.R. (1991) Effects of interactions between nutrition and negative feedback on the secretion of gonadotrophins in castrated merino rams. Proceedings of the Australian Society for Reproductive Biology 23, 71 .

Underwood, E.J. (1981) The Mineral Nutrition of Livestock (2nd Edn) pp. 135-145. Commonwealth Agricultural Bureaux, Slough.

Underwood, E.J. \& Somers, M. (1969) Studies of zinc nutrition in sheep. I. The relation of zinc to growth, testicular development and spermatogenesis in young rams. Australian Journal of Agricultural Research 20, 889-897.

Received 14 August 1991 